\title{
Willingness to Communicate and Language Learning Orientations in Iranian EFL Context
}

\author{
Nourollah Zarrinabadi \\ Department of English Language and Literature \\ Allameh Tabataba'i University, Tehran, Iran \\ E-mail: Nur.zarrinabadi@gmail.com \\ Razieh Abdi \\ Department of English Language and Literature \\ University of Isfahan, Isfahan, Iran \\ E-mail: Abdi.razieh@gmaill.com
}

Received: May 26, 2011 Accepted: June 9, $2011 \quad$ Published: November 1, 2011

doi:10.5539/ies.v4n4p206 URL: http://dx.doi.org/10.5539/ies.v4n4p206

\begin{abstract}
The objective of this study is to investigate the relationship between Iranian EFL Learners' willingness to communicate (WTC) inside and outside the classroom and their language learning orientations. Sixty seven intermediate students (36 males and 31 females) who were majoring in English Literature and Translation at University of Isfahan during the academic year of 2010-2011 participated in the study. The students were bilingual and their age ranged from 19 to 24. Modified versions of likert-type questionnaires developed by MacIntyre, Baker, Clement, and Conrod (2001) were used for measuring students' willingness to communicate inside and outside the classroom and language learning orientations. The data obtained from the study indicated language orientations to be more correlated with willingness to communicate outside than inside the classroom.
\end{abstract}

Keywords: Willingness to Communicate Inside the Classroom, Willingness to Communicate Outside the Classroom, Language Learning Orientation

\section{Introduction}

Research on second language acquisition indicates that affective factors like attitude, anxiety, and motivation have an effective role in language achievement and proficiency (Yashima 2002). One of these affective factors is willingness to communicate (WTC), a variable which affects authentic communication in L2 and has been considered as a good predictor of frequency of communication. The current study focuses on the relationship between WTC inside and outside the classroom and language learning orientations of Iranian EFL learners.

\subsection{Origins of $W T C$}

Burgoon (1976) originated the first construct on this field. She called her construct "Unwillingness to Communicate" and defined it as "enduring and chronic tendency to avoid or devalue oral communication." She reported that variables like anomie and alienation, introversion, self-esteem, and communication apprehension affect a person's willingness for communication in different communication situations. Mortensen, Arnston, and Lustig (1977) discussed that the more global features of speech are to be consistent and enduring from one social setting to another. They called their model Predisposition Toward Verbal Behavior. They believed that this is a characteristic predisposition to talk a given amount and that predisposition operates within the constraints of individual situations. Mortensen et al. (1977) do not mention any possible causes for the Predisposition Toward Verbal Behavior. The next model related to WTC was "Shyness"'. Shyness was a construct developed by McCroskey and Richmond (1982) who defined it as the "tendency be timid, reserved, and most specifically, talk less." They produced a self-report scale for measuring shyness which was reported to be a valid predictor of the amount of speaking in which individuals engage. The shyness model proposed by McCroskey and Richmond (1982) do not claim the existence of a personality-based, trait-like predisposition to be willing to communicate or not. Based on the above studies McCroskey and Baer (1985) developed the WTC construct in L1 for the first time. 


\subsection{WTC as the Objective of Language Instruction}

Dornyei (2003) states that many L2 learners tend to avoid second language communication. Based on this idea Kang (2005) argues many L2 learners may not use the opportunities to learn language through authentic communication. MacIntyre et al. (1998) believe that producing WTC is a crucial component of modern language instruction. They argue that current emphasis on communicative competence may produce students capable of communication inside the classroom, but these students "may not be amenable to do so outside the classroom. Kang (2005) reports that teachers will have more active learners by making them more willing to communicate. Kang states that students with high WTC are more likely to use L2 in authentic communication and function as autonomous learners by making independent efforts to learn language. He also believes that students with high WTC will have their learning opportunities and become involved in learning activities both inside and especially outside the classrooms. The importance of WTC reaches to an extent that scholars like Dornyei (2005) consider it as the "ultimate goal of instruction."

\subsection{WTC as a Trait-like Predisposition}

The concept of WTC was developed from Burgoon's (1976) concept of unwillingness to communicate which was first hypothesized as a personality characteristic and a trait-like predisposition to account for individual differences in L1 communication. Based on the findings of Burgoon (1976), Mortensen et al. (1977) and McCroskey and Richmond $(1982,1987,1990)$ proposed WTC to be the individuals' tendency to initiate communication when they are free to do so. They proposed WTC to be a trait-like predisposition.

Based on this view, researchers have investigated the influence of an individual's variables on WTC. Among all variables, perceived communicative competence and communication apprehension were found to be the best predictors of WTC (Baker and McIntyre 2000; McIntyre 1994; McIntyre et al. 2001; McCroskey and Richmond1991).

\subsection{WTC as a Situational Construct}

McIntyre, Clement, Dornyei, and Noels (1998) discussed that it is not necessary to limit WTC to a trait-like variable. They conceptualized WTC as a situational variable with both transient and enduring variables. They defined L2 WTC as "a readiness to enter into discourse at a particular time with a specific person or persons, using a L2" (p. 547). They provided a pyramid model of the variables affecting WTC as shown in figure 1.

There are six layers in the pyramid model. The first three layers of the model refer to those variables which have situation-specific effect on individual's WTC, and the next three layers include those variables with enduring influence on WTC. The first layer of the model is authentic communication in the second language. This includes activities like reading a book or speaking in second language in the classroom. In second language, there is WTC as the immediate variable behind communicative use of language. Layer three of the pyramid depicts the desire to communicate with specific persons and state communication self-confidence as the situated antecedents of communication. State self-confidence refers to the feeling of having the capacity to communicate effectively at a particular moment. Layer four shows the role of motivational propensities which tend to be stable individual variables: interpersonal motivation, intergroup motivation, and second language self-confidence. Interpersonal and intergroup motivation are the basic factors affecting desire to communicate with specific persons in the third layer. The fifth layer is devoted to those variables that are to some extent remote from language learning and communication context. The variables mentioned in this layer are intergroup attitude, social situation and communicative competence. Variables in this layer affect WTC by having influence on the variables discussed in the preceding layers. The last layer of the pyramid is the layer of social and individual context. Here, social context alludes to intergroup climate. And individual context refers to those personality variables related to communication. Reflecting on this situational view, researches have shown that WTC is subject to some situational variables (Baker and MacIntyre 2000; Clement et al. 2003; MacIntyre et al. 2001)

\subsection{Language Learning Orientations}

Belmechri and Hummel (1998) defined orientations as those "long-range goals which along with attitudes sustain a student's motivation to learn a second language." Gardner and Lambert (1959) identify two categories of orientation: first is integrative orientation which is a positive disposition toward the second language group and desire to interact and become a member of that group. The second is instrumental orientation which is related to pragmatic goals of learning a second language. Finding a job or increasing salary of instrumental orientations. The importance of orientations in language learning is intertwined with the importance and role of motivation in learning a second language. Gardner and Lambert $(1959,1972)$ suggested that a person's motivation for learning a second language is affected by both orientation for acquisition of the second language and the attitude toward second language group. 
Some studies conducted emphasized the positive role of integrative orientation on language learning (Gardner and Lambert, 1959), but some studies found negative correlation between integrative orientation and proficiency (Lukmani, 1972; Chihara \& Oller, 1978). Considering these inconsistencies, Clement and Kruidenier (1983) claimed that social milieu plays a drastic role and the above differences in research findings are due to this reason. They investigated the orientations of French and English high school students of Spanish, English, and French and found that integrative orientation exists only in members of dominant group in multicultural context. They found four orientations for all groups: travel, friendship, knowledge, and instrumental orientations. In another study conducted by Belmechri and Hummel (1998), travel, understanding/ school (instrumental), friendship, understanding and career (instrumental) were found to be most important of orientations for grade 11 high school students learning ESL in Quebec City francophone context.

There is just one study directly addressing the relationship between WTC and language learning orientations which was conducted by MacIntyre et al. (2001). Since the ethno-linguistic vitality as pointed out by Giles, Bourhis and Taylor (1977) and Giles and Byrne (1982) is the variable which modifies and influences L2 learning. This study aims to investigate the relationship between WTC and language learning orientations in Iranian EFL context.

\section{This Study and Research Questions}

This study tries to investigate the relations between WTC and language learning orientations in Iranian EFL context. The authors followed the methodology used by MacIntyre et al. (2001) for investigating the relationship between Canadian students' language learning orientations and their WTC in the current study to develop a clearer understanding of the relationship in Iranian EFL context.

\subsection{Research Questions}

This study attempts to answer the following questions:

1: Which view of WTC the data supports?

2: Is there any relationship between Iranian students' language learning orientations and WTC both inside and outside the classroom?

\section{Methodology}

\subsection{Participants}

67 upper-intermediate students (36 males and 31 females) who were majoring in English Literature and Translation at University of Isfahan during the academic year of 2010-2011 took part in the study. All the students were bilingual and between 19 to 24 years old.

\subsection{Instruments}

\subsubsection{Willingness to communicate inside the classroom}

A modified version of the likert-type questionnaire developed by MacIntyre et al. (2001) was used for measuring students' willingness to communicate inside the classroom. The scale comprises of 27 items which range from 1 to $5(1=$ almost never willing, $2=$ sometimes willing, $3=$ willing half of the time, $4=$ usually willing, and $5=$ almost always willing). Students were asked to indicate how much willing they would be to communicate during the class tasks. The items were written in a way that involved students' willingness to communicate inside the classroom in all four skills. MacIntyre et al. (2001) report this scale to be a valid and reliable one (alpha levels indicate reliability estimates): speaking ( 8 items, $\alpha=.81$ ), comprehension ( 5 items, $\alpha=.83$ ), reading ( 6 items, $\alpha=.83$ ), and writing ( 8 items, $\alpha=.88)$. The alpha reliability estimates for this instrument in the current study are as follows: speaking $(8$ items, $\alpha=.78$ ), comprehension (5 items, $\alpha=.79$ ), reading ( 6 items, $\alpha=.85$ ), and writing ( 8 items, $\alpha=.85$ ).

\subsubsection{Willingness to communicate outside the classroom}

Modified version of Willingness to communicate outside the classroom questionnaire (see Appendix B) which was used for measuring students' willingness to communicate outside the classroom was developed by MacIntyre et al. (2001). The scale contains 27 items in a likert-type manner ranging from 1 to $5(1=$ almost never willing, $2=$ sometimes willing, 3 = willing half of the time, $4=$ usually willing, and $5=$ almost always willing). The students were wanted to indicate their level of willingness by putting the number most suits them immediately after each item. The scale proved to be a reliable measure of students' willingness to communicate outside the classroom in all four skills: speaking ( 8 items, $\alpha=.89$ ), comprehension ( 5 items, $\alpha=.90$ ), reading ( 6 items, $\alpha=.93$ ) and writing ( 8 items, $\alpha=.96)$. The alpha reliability estimates for this instrument in the present study are as follows: speaking ( 8 items, $\alpha$ $=.82$ ), comprehension (5 items, $\alpha=.79)$, reading ( 6 items, $\alpha=.88$ ) and writing ( 8 items, $\alpha=.93$ ).

3.2.3 Orientations for language learning 
Students indicated their language learning orientations by answering a likert-type scale. The questionnaire is adapted from MacIntyre et al. (2001) produced on a scale from 1 to 6 , where $1=$ strongly agree, $2=$ moderately agree, $3=$ mildly agree, $4=$ mildly disagree, $5=$ moderately disagree, and $6=$ strongly disagree. Travel, job-related, knowledge, friendship and language achievement are the orientations presented in the scale. MacIntyre et al. (2001) adapted the items from those used by Clement and Kruidenier (1983).Four items are dedicated to measure each orientation: travel $(\alpha=.71)$, knowledge $(\alpha=.70)$ friendship $(\alpha=.81)$, job-related $(\alpha=.73)$, and school achievement $(\alpha=.66)$. The researchers modified the questionnaire in order to make it suitable for measuring the Iranian EFL learners' orientations. The alpha reliability estimates for this instrument in the current study are as follows: travel ( $\alpha$ $=.80)$, knowledge $(\alpha=.69)$ friendship $(\alpha=.83)$, job-related $(\alpha=.81)$, and school achievement $(\alpha=.64)$.

\subsection{Procedure}

After the permission was granted by university administration and professors, those classes with upper-intermediate students were chosen for measurement administration. Before administering the questionnaires, the participants were informed that they have the right to decline taking part in the study. They were informed that the data will be scored anonymously. After the participants' consent was assured, three questionnaires were administered to the students. A time period of 30 minutes was allocated to testing and then the questionnaires were collected. Because the study was a correlational one, the authors decided to present three measures together for timesaving and ease of administration.

\subsection{Data Analysis and Results}

After administering the questionnaires, the raw data were analyzed by SPSS 18 software. The results are presented in the following parts regarding each research question.

\subsubsection{Trait-like or a situational one?}

First, the inter-correlations for WTC inside and outside the classroom were computed. All the correlations were significant and varied from .46 to .68. The correlations show a substantial overlap between WTC inside and outside of the classroom for all language skills: speaking, reading, writing, and comprehension. This overlap supports the trait-like view of WTC proposed by McCroskey and Richmond (1991).

\subsubsection{WTC and language learning orientations}

Correlations for the relationship between WTC inside and outside the classroom and orientations for language learning are shown in Table.1.Among the five orientations, School and knowledge-related ones correlate with willingness to communicate both inside and outside the classroom. Job, travel, and friendship correlations are correlated with WTC in four language skills only outside the classroom. There are L2 significant correlations between WTC inside the classroom and orientations for language learning. However, the number of significant correlations between WTC outside the classroom and language learning orientations is 19. This situation happened in the study by MacIntyre et al. (2001) who found more correlations among WTC outside the classroom and language learning orientations. This can be claimed that orientations for language learning are more correlated with WTC outside the classroom irrespective of the culture or first language. The correlation between WTC inside the classroom and travel orientation is weak because travel is more related to the out of class affairs than the inside ones.

\section{Conclusion}

The current study aimed at investigating the relationship between WTC and language learning orientations of Iranian EFL learners. First, the study investigated the relationship between students WTC inside and outside of the classroom in order to see that the data will support for which view of WTC. Calculation of Pearson product moment correlations supported a trait-like view of WTC as proposed by McCroskey and Richmond (1991). In the second part of the study the correlations between students' WTC and language learning orientations were calculated. Like the similar study conducted by MacIntyre et al. (2001), this study found strong correlation between language learning orientations and WTC inside and outside the classroom (especially WTC outside the classroom). Orientations are important in that they affect students' motivation for learning a second language (Gardner and Lambert, 1959, 1972) and the amount of time and energy they spend for learning a language. This importance will be grasped more considering the fact that motivation is a variable which drastically affects students' WTC (as discussed in the pyramid model).

Considering the emphasis modern approaches to language teaching puts on communication and authentic language use, it is believed that those students are successful who benefit from a higher level of WTC (MacIntyre et al. 2001). Changing the focus of language instruction from linguistic and grammatical competence toward an approach based on learners' needs, which students' orientations for learning a language can indicate, will be possible when students 
are willing to use L2 outside the classroom and act independently for finding conversation opportunities. The question of what can be done for considering students' language learning orientation in actual classroom milieu to create WTC will remain to be studied. Finally, it should be mentioned that there were variables like students' gender not controlled for which can affect the results of the study.

\section{Acknowledgment}

The authors would like to thank Dr. Shiri, Dr. Abasi, and Dr. Tahmasebian at Isfahan University for their nice cooperation during conducting this study. We also thank Dr. Fahimeh Marefat at Allameh Tabataba'i University who taught us second language research. Thanks also go to the three anonymous reviewers for their valuable feedbacks on the earlier version of the article.

\section{References}

Baker, S. C., \& MacIntyre, P. D. (2000). The role of gender and immersion in communication and second language orientations. Language Learning, 50, 311-341. http://dx.doi.org/10.1111/0023-8333.00119

Burgoon, J. K. (1976). The Unwillingness-to-Communicate Scale: development and validation. Communication monograph, 43, 60-69

Clement, R., Baker, S. C., \& MacIntyre, P. D., (2003). Willingness to communicate in a second language: the effect of context, norms, and vitality. Journal of Language and Social Psychology, 22, 190-209. http://dx.doi.org/10.1177/0261927X03022002003

Dornyei, Z. (2003). Attitudes, orientations, and motivations in language learning: advances in theory, research, and applications. Language Learning, 53, 3-32. http://dx.doi.org/10.1111/1467-9922.53222

Dornyei, Z. (2005). The psychology for language learner: individual differences in Second Language Acquisition. Mahwah, N.J.: Lawrence Erlbaum.

Gardner, R. C., \& Lambert, W. E. (1959). Motivational variables in second language acquisition. Canadian Journal of Psychology, 13, 266-272

Gardner, R. C., \& Lambert, W. E. (1972). Attitudes and motivation in second language learning. Rowley, MA: Newbury House.

Giles, H., Bourhis, R. Y., \& Taylor, D. M. (1977). Toward a theory of Language in Ethnic group relations. In H. Giles (Ed.), language, ethnicity, and intergroup relations (pp. 307-348) London: Academic Press.

Giles, H., \& Byrne, J. L. (1982). An intergroup approach to second language acquisition. Journal of multilingual and multicultural development, 3, 17-40. http://dx.doi.org/10.1080/01434632.1982.9994069

Kang, S. (2005). Dynamic emergence of situational willingness to communicate in a second language. System, 33: 227-92. http://dx.doi.org/10.1016/j.system.2004.10.004

MacIntyre, P. D. (1994). Variables underlying willingness to communicate: A causal analysis. Communication Research Reports, 11, 135-142. http://dx.doi.org/10.1080/08824099409359951

MacIntyre, P. D., Baker, S. C., Cle'ment, R., \& Conrod, S. (2001). Willingness to communicate, social support, and language-learning orientations of immersion students. Studies on Second Language Acquisition, 23, 369-388

MacIntyre, P. D., \& Charos, C. (1996). Personality, attitudes, and affect as predictors of second language communication. Journal of Language and Social Psychology, 15, 3-26. http://dx.doi.org/10.1177/0261927X960151001

MacIntyre, P., Clement, R., Dornyei, Z., \& Noels, K. (1998). Conceptualizing willingness to communicate in a L2: A situational model of L2 confidence and affiliation. The Modern Language Journal, 82, 545-562. [Online] Available: http://www.jstor.org/stable/330224

McCroskey, J. C., \& Baer, J. E. (1985). Willingness to communicate: The construct and its measurement. Paper presented at the annual convention of the Speech Communication Association, Denver, Colorado.

McCroskey, J. C \& Richmond, V. P. (1980). The quiet ones: shyness and communication apprehension. Scottsdale, Gorsuch Scarisbric.

McCroskey, J. C., \& Richmond, V. P. (1982). Communication apprehension and shyness: Conceptual and operational distinctions. Central States Speech Journal, 33, 458-468. http://dx.doi.org/10.1080/10510978209388452

McCroskey, J. C., \& Richmond, V. P. (1987). Willingness to communicate. In J. C. McCroskey\& J. A. Daly (Eds.), Personality and interpersonal communication (pp. 129-156). Newbury Park, CA: Sage. 
McCroskey, J. C., \& Richmond, V. P. (1990). Willingness to communicate: differing cultural perspectives. Southern Communication Journal, 56, 72-77. http://dx.doi.org/10.1080/10417949009372817

McCroskey, J. C., \& Richmond, V. P. (1991). Willingness to communicate: A cognitive view. In M. Booth-Butterfield (Ed.), Communication, cognition, and anxiety (pp.19-37). Newbury Park, CA: Sage.

Mortensen, C. D., Arntson, P. H., \& Lustig, M. (1977). The measurement of verbal predispositions: Scale development and application. Human Communication Research, 3, 146-158. http://dx.doi.org/10.1111/j.1468-2958.1977.tb00513.x

Yashima, T. (2002). Willingness to communicate in a second language: The Japanese EFL context. Modern Language Journal, 86, 55-66. http://dx.doi.org/10.1111/1540-4781

Table 1. Correlations among Students' Orientations and WTC Inside and Outside the Classroom

Orientations

$\begin{array}{lccccc}\text { Skills } & \text { Job } & \text { Travel } & \text { Friendship } & \text { Knowledge } & \text { School } \\ \text { WTC Inside } & & & & & \\ \text { Speaking } & .33^{*} & .21 & .39^{* *} & .41^{* *} & .34^{* *} \\ \text { Reading } & .21 & .25 & .23 & .33^{*} & .33^{*} \\ \text { Writing } & .33^{*} & .29 & .21 & .37^{* *} & .41^{* *} \\ \text { Comprehension } & .24 & .23 & .36^{* *} & .32^{* *} & .34^{*} \\ \text { WTC Outside } & & & & & \\ \text { Speaking } & .51^{* *} & .37^{* *} & .51^{* *} & .44^{* *} & .41^{* *} \\ \text { Reading } & .42^{* *} & .21 & .34^{*} & .34^{*} & .46^{* *} \\ \text { Writing } & .33^{* *} & .30^{*} & .34^{*} & .35^{* *} & .45^{* *} \\ \text { Comprehension } & .46^{* *} & .34^{* *} & .42^{* *} & .32^{*} & .32^{*} \\ .01 ; * * p .001 & & & & & \end{array}$

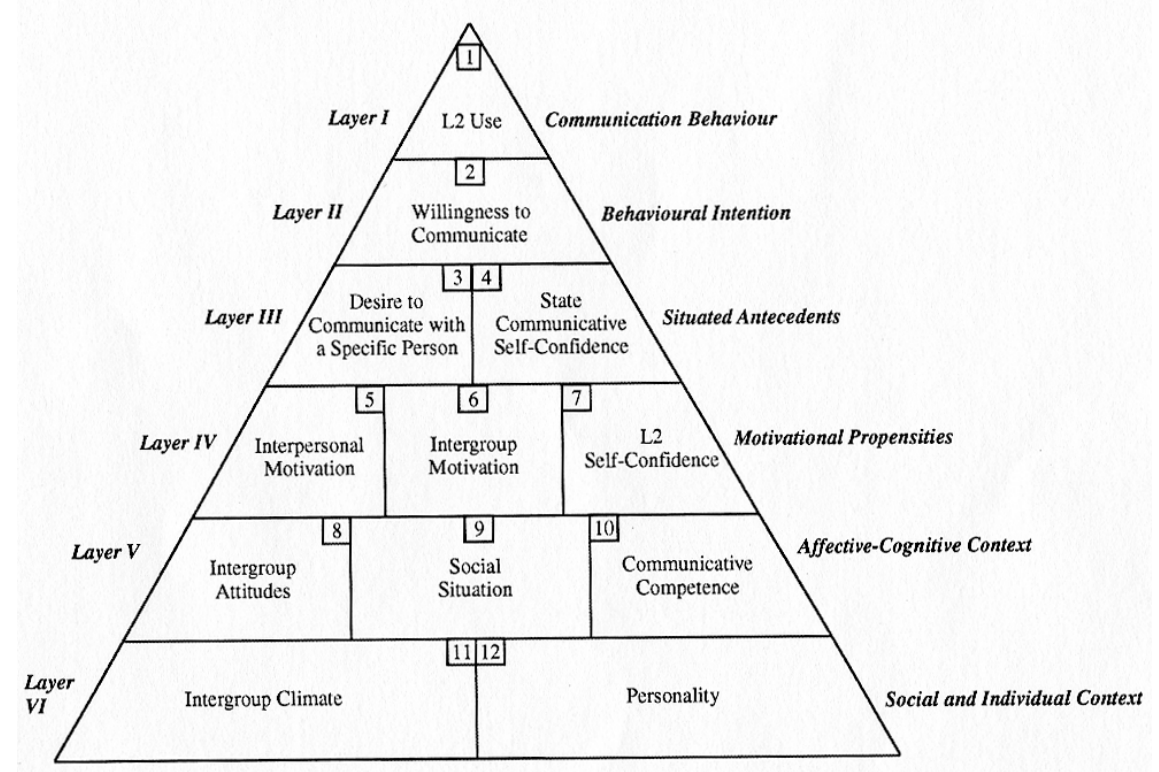

Figure 1. Schematic representation of the variables influencing WTC. From "Conceptualizing Willingness to Communicate in a L2: A Situated Model of Confidence and Affiliation," by P. D. MacIntyre, R. Clément, Z. Dörnyei, and K. Noels, 1998, Modern Language Journal, 82, p. 547. Copyright 1998 by The Modern Language Journal. Reprinted with permission. 


\section{Appendix A: REVISED VERSION OF WILLINGNESS TO COMMUNICATE INSIDE THE CLASSROOM (MacIntyre et al., 2001)}

We would like to appreciate you for your nice cooperation. Please, read the following statements carefully and answer them according to the instructions prepared.

Directions: This questionnaire is composed of statements concerning your feelings about communication with other people, in English. Please indicate in the space provided the frequency of time you choose to speak in English in each classroom situation.

If you are almost never willing to speak English, write 1. If you are willing sometimes, write 2 or 3 . If you are willing most of the time, write 4 or 5 .

$1=$ Almost never willing

$2=$ Sometimes willing

$3=$ Willing half of the time

$4=$ Usually willing

$5=$ Almost always willing

\section{Speaking in class, in English}

1. Speaking in a group about your summer vacation.

2. Speaking to your teacher about your homework assignment

3. A stranger enters the room you are in, how willing would you be to have a conversation if he talked to you first?

4. You are confused about a task you must complete, how willing are you to ask for instructions/clarification?

5. Talking to a friend while waiting in line.

6. How willing would you be to be an actor in a play? ......

7. Describe the rules of your favorite game.

8. Play a game in English.......

\section{Reading in class (to yourself, not out loud)}

1. Read a novel.

2. Read an article in a paper.

3. Read letters from a pen pal written in native English. ......

4. Read personal letters or notes written to you in which the writer has deliberately used simple words and constructions.

5. Read an advertisement in the paper to find a good bicycle you can buy.......

6. Read reviews for popular movies. ......

\section{Writing in class, in English}

1. Write an advertisement to sell an old bike

2. Write down the instructions for your favorite hobby.

3. Write a report on your favorite animal and its habits.

4. Write a story

5. Write a letter to a friend

6. Write a newspaper article.

7. Write the answers to a "fun" quiz from a magazine. ......

8. Write down a list of things you must do tomorrow.

\section{Comprehension in class}

1. Listen to instructions and complete a task

2. Bake a cake if instructions were not in Persian. 
3. Fill out an application form.

4. Take directions from an English speaker. ......

5. Understand an English movie.......

\section{Appendix B: REVISED VERSION OF WILLINGNESS TO COMMUNICATE OUTSIDE THE CLASSROOM (MacIntyre et al., 2001)}

Directions: Sometimes people differ a lot in their speaking, reading, and so forth in class and outside class. Now we would like you to consider your use of English outside the classroom. Again, please tell us the frequency that you use English in the following situations. Remember, you are telling us about your experiences outside of the classroom this time. There are no right or wrong answers.

$1=$ Almost never willing

$2=$ Sometimes willing

$3=$ Willing half of the time

$4=$ Usually willing

$5=$ Almost always willing

\section{Speaking outside class, in English}

1. Speaking in a group about your summer vacation.

2. Speaking to your teacher about your homework assignment. ......

3. A stranger enters the room you are in, how willing would you be to have a conversation if he talked to you first? ......

4. You are confused about a task you must complete, how willing are you to ask for instructions/clarification? ......

5. Talking to a friend while waiting in line.......

6. How willing would you be to be an actor in a play? ......

7. Describe the rules of your favorite game......

8. Play a game in English. ......

\section{Reading outside class, in English}

1. Read a novel.

2. Read an article in a paper.

3. Read letters from a pen pal written in native English.

4. Read personal letters or notes written to you in which the writer has deliberately used simple words and constructions.

5. Read an advertisement in the paper to find a good bicycle you can buy.

6. Read reviews for popular movies.

\section{Writing outside class, in English}

1. Write an advertisement to sell an old bike.

2. Write down the instructions for your favorite hobby.

3. Write a report on your favorite animal and its habits.

4. Write a story.

5. Write a letter to a friend.

6. Write a newspaper article.

7. Write the answers to a "fun" quiz from a magazine

8. Write down a list of things you must do tomorrow.

\section{Comprehension outside class}

1. Listen to instructions and complete a task. 
2. Bake a cake if instructions were not in Persian.

3. Fill out an application form.

4. Take directions from an English speaker.

5. Understand an English movie.

\section{Appendix C: REVISED VERSION OF ORIENTATIONS FOR LANGUAGE LEARNING (MacIntyre et al., 2001)}

We are interested in your reasons for studying English. Please indicate the extent to which you consider each of the following to be important reasons for you to study English. Write the appropriate number in the space provided.

$1=$ Strongly agree

$2=$ Moderately agree

$3=$ Mildly agree

$4=$ Mildly disagree

$5=$ Moderately disagree

$6=$ Strongly disagree

Studying English is important because:

1. It will be useful in getting a good job

2. I would like to travel in England

3. I would like to meet some English people.

4. It will help me understand English people and their way of life

5. I will need English for my career in the future.

6. I would like to go to U.S.A

7. I would like to be friends with some English people.

8. It will help me to be successful in business

9. It will help me to get a better paying job.

10. It will make me a more knowledgeable person

11. It will help me if I travel.

12. It will enable me to make friends more easily among English-speaking people.

13. It will help me acquire new ideas and broaden my outlook.

14. I would like to travel to an English-speaking area.

15. It will help me get to know English-speaking people

16. It will help me learn about myself.

17. It will help me to get good grades

18. It will help me get into better schools later in life.

19. It will give me a better education.

20. I get high marks in English. 